\title{
More Venezuelans in Trinidad in the 21st century
}

\section{A brief account and analysis of the first large-scale irregular migration of Venezuelans to Trinidad and Tobago in recent years}

\section{Chinyere Herbert ${ }^{1}[0$}

Received: 10 December 2020 / Accepted: 15 September 2021 / Published online: 08 November 2021 (c) The Author(s) 2021

\begin{abstract}
Venezuelan 'asylum seekers' arriving at the coast of Trinidad enter a new reality and become a part of a world of politics and processing like most migrants do. By no fault of their own, they embody local and global tensions concerning migration policies, border control, government authority, and international human rights and protection. This paper raises questions about the complex status and identity of Venezuelan migrants in Trinidad who came seeking asylum in recent years. The results demonstrate that internationally accepted "refugee" and "asylum seeker" categorization is highly unstable in the present context due to the core economic issues underlying forced migration. In line with previous anthropological research, the study highlights the ways in which labels do not encapsulate the local and global causes underlying forced migration and displacement. While international law is wellmeaning, there remains a lot to be desired in the long-term protection of displaced people. There are also geographic and economic limits of small islands to absorb large numbers of displaced persons which, to date, has not been recognized by international human rights organizations.
\end{abstract}

Keywords Refugees · Asylum seekers · Economic migrants · Identity · Policy · Practice $\cdot$ UNHCR $\cdot$ Venezuelans $\cdot$ Trinidad and Tobago

This article is an adaptation of a dissertation submitted in partial fulfilment of the requirements for the Degree of M.A. in Linguistics and Social Anthropology 11/2019 by Chinyere Herbert.

Chinyere Herbert

chinyere.herbert@outlook.com

1 The University of Edinburgh, Edinburgh, Scotland 


\section{Literature Review}

This introduction briefly highlights the history of international refugee law, introduces debates in refugee studies, and explains the relevant complexities surrounding the categorization of irregular migrants.

The Geneva Convention in Post-World War II was the historical moment in which the 'refugee' identity was first established (Malkki 1995). Initially, refugee camps emerged as an ad-hoc short term solution to the post-War displacement of people in Europe (ibid.). The control of displaced persons was a military and security issue rather than a cause for humanitarian concern (ibid.). Nonetheless, humanitarian laws and practices arose over the following years.

At the 1951 Geneva Convention, there was the formation of the universal definition of the refugee with many codes in line with UN human rights declarations. This definition is still used today in the refugee determination process:

[T]he term 'refugee' shall apply to any person who[,] ... owing to well-founded fear of being persecuted for reasons of race, religion, nationality, membership of a particular social group or political opinion, is outside the country of his nationality and is unable or, owing to such fear, is unwilling to avail himself of the protection of that country; or who, not having a nationality and being outside the country of his former habitual residence as a result of such events, is unable or, owing to such fear, is unwilling to return to it (UN Geneva Convention 1951).

In light of this definition, much has been written in the last 50 years in academia concerning 'refugee' identity, policy and practice. According to various studies, there is a complex history of refugee categorization and experiences despite the simple definition upheld by humanitarianism, organizations and asylum regimes (see Malkki 1995; Feldman 2012; Goodman and Speer 2007; Keller 1975; Robertson 2018; Stein 1981; Zetter 1991).

Theoretically, there has been an emergence of an identifiable 'refugee' experience. There have been indicators that unify the experience of becoming a 'refugee' put forward by researchers such as Stein (1981) and Keller (1975). They have argued that there is a 'refugee' experience' that is recognizable in many historical displacement contexts. Put simply, the 'refugee' experience entails physical displacement, losing belonging and identity in their country of origin and forming a new identity in a host country (Stein 1981). The refugee experience also includes the perception of a threat, a decision to flee the extreme danger or flight, arriving safely, registration, repatriation, settlement or resettlement (Keller 1975). This unified 'refugee experience' is of interest as it provides a theoretical framework for analysis. This will be explored in the present study to identify how Venezuelan migrants fit into this 'refugee' experience narrative.

On the other hand, other researchers have identified that essentializing the 'refugee' experience is problematic in various ways. The classification involved in migrant status is static and legal, and it does not account for the dynamic, relational (foundationally concerned with the creation of boundaries between different groups) 
and intersectional (bound up with other categories of social difference) conditions involved in becoming a 'refugee' (Robertson 2018: 220). For example, there is an uncomfortable emphasis on the country of origin that makes it seem that migrants' identities in their countries of origin are always unproblematic and perfect until there is a crisis (Malkki 1995). Through the typical 'refugee' experience narrative, identity is whole only when rooted in the homeland, the country of long-term previous residence or birth (ibid.). This origin assumption reinforces the idea that state sovereignty as we know it at the beginning of the 21 st century, is part of a natural or necessary order of things (Malkki 1995: 11). The closing of borders against asylum applications based on cultural differences and 'true' belonging can then be justified and naturalized (ibid.). In this light, Malkki (1995) states that in studying refugees, we tend towards essentialism and functionalism which should be reconsidered, perhaps especially in a more globalized world (ibid.). Thus, this argument underscores that some awareness about the relational, dynamic and intersectional identity of 'refugees' remains understated and important. From this perspective, understanding the macro power dynamics and subtle socio-cultural justification is required to produce non-normative discourse and more dynamic policy and practice that affects those experiencing 'forced' migration.

Hence, these conflicting theories, the unified 'refugee' experience and the essentialism critiques provide relevant examples of the dichotomous analyses present in the current refugee literature. Therefore, the present study will attempt to investigate Venezuelan migrant experiences through the cited "refugee" experience lens while also attempting to centralize a non-essentialist analysis in line with the critical literature.

Furthermore, previous research has also explained how labels and categorization affect migrant legitimacy and perceived identity in ways that are often unrecognized. The category constructions of 'asylum seeker', 'refugee', 'economic migrant', 'illegal immigrant' and 'bogus asylum seeker' get utilized, distinguished and conflated in the asylum debate (Goodman and Speer 2007). By categorizing asylum seekers in terms of those genuinely fleeing persecution and those economic migrants, the public sphere debate becomes one about the legitimacy or illegitimacy of asylum seekers claims (Goodman and Speer 2007: 179). Categorizing asylum seekers in this way has the unfortunate consequence of constructing all asylum seekers as immigration 'cheats' and as untrustworthy and dishonest people whom we are right to treat with doubt and contempt (ibid.) More evidence is necessary to verify the underscored attitudes. However, the authors raise points for consideration about the consequence of labelling and subliminal negative attitudes towards people categorized as asylum seekers.

In a similar way, due to their partial foundations, labels do not capture migrant experiences in holistic ways according to some researchers. According to Zetter (1991), 'refugee' labels are imposed, partial and symbolic. They do not capture the dynamic nature of identity and personhood of those affected by 'forced' migration. Notably, Goodman and Speer (2007) also state that an asylum seeker is perhaps, more appropriately termed a refugee applicant since 'asylum seeker' denotes someone who seeks something from the host country. Hence, with the categorization and 
labelling of migrants, there are consequences of deploying terms in 'refugee' or 'asylum seeker' discourse and practice which likely require more sensitivity.

Concerning Venezuelan migrants in Trinidad, there has only been one official study worth mentioning. In a refugee report sponsored by Refugees International, Teff (2019), under the title, 'Forced into illegality', highlights that Venezuelans are not given legal status easily in Trinidad. Venezuelans generally struggle with detention, refoulment back to Venezuela, and face problems with gaining full legal status and safe working conditions in Trinidad risking dangerous situations like illegal trafficking and discrimination (ibid). Suggestions are made to the government of Trinidad and Tobago by Teff (2019) from the perspective of international protection of all asylum seekers. The author calls for a better migration policy from the government of Trinidad to create more opportunities for work and regularize Venezuelans' status. Teff (2019) also urges for an anti-xenophobia campaign owing to stereotypes and discrimination reported by Venezuelan migrants in the author's enquiry. This case study by Teff (2019) presents themes of interest, the status of Venezuelans in Trinidad, stereotypes, discrimination of migrants and the obligation of the government of Trinidad and Tobago to aid Venezuelans which is relevant for further investigation in the present study. As the situation continued in the following years after the study by Teff (2019), the government of Trinidad and Tobago responded to the crisis with an amnesty period for Venezuelans where their status could be regularised. This will be analyzed further in the data and following discussions.

When analyzing the experiences of 'refugees', sensitivity to essentialism, labelling and holistic identity are necessary as the above literature indicates. Thus, a more lived experience approach will be centralized in the current study. As Robertson (2018) highlights, international migration studies has critiqued migrant status (and categorization) as problematic and often contests dichotomous legal divisions or highlights disjunctions between legal categories and everyday experiences. Notably, she emphasizes that migrant categorization and status research can benefit from including migrant voices by sharing more lived experiences in future.

Therefore, through these theoretical lenses, this study aims to explore how Venezuelan migrants fit or do not fit into "refugee", "asylum seeker" and "economic migrant" categories and further analyzes the socio-cultural, and economic factors affecting Venezuelans in Trinidadian society in the 21st Century.

\section{Background: Venezuelan crisis and Trinidad and Tobago}

According to the UNHCR, the world organization for the registration and protection of asylum-seekers, Venezuelans are one of the single largest population groups displaced from their country. At present, they are fleeing for reasons such as violence, food insecurity and medicine shortages (UNHCR 2021). According to their official website, the number of Venezuelans who have left their country reached an estimated 5.4 million in 2021 (ibid.). Per the UNHCR and the International Organization for Migration (IOM), Latin American countries are hosting millions of Venezuelan 'refugees': Colombia (1.3 million), Peru $(768,000)$, Chile $(288,000)$, Ecuador (263,000), Argentina (130,000), and Brazil (96,000) (IOM 2021). Countries in 
Central America and the Caribbean also host significant numbers of refugees and migrants (ibid.)

Trinidad and Tobago, the site of this study, reportedly received fewer 'refugees' than other countries. Yet, considering the population of 1.4 million, its overall size of 1980 sq. miles, the proximity of the islands to Venezuela and the government's migration policy changes, the location remains an important site. The estimate of Venezuelans in Trinidad in 2019 was approximately 40,000 migrants, the highest number of Venezuelans any country has received per capita (ibid).

This '40,000' figure is ubiquitous from many credible organizations such as the UNHCR, Local News Reports, and LWC Centre for Refugees and Asylum-seekers where this research was undertaken. However, there is a level of scrutiny that must be applied to this number since it embodies a central conflict in terms of monitoring and registering asylum seekers.

The accuracy of the 40,000 quoted estimation has been contested. Some have denounced the figure as an overestimate, while others insist it is an underestimate. The figure may be an underestimate due to the high potential and reports of many 'illegal' or 'unregistered' or 'undocumented' migrants remaining under the processing radar, i.e. in hiding.

In Trinidad, there have been local news reports of Venezuelans found hiding in forests on the Western coast (De Silva 2019). They did not wish to make themselves known to the government or the UNHCR. As one of my Trinidadian informants, a local staff member at the center jokingly said to me, "At this point, we must be halfhalf, because everywhere you go in Trinidad, you see a 'Vene' [colloquial way of referring to Venezuelans], you see a Trini [colloquial way of calling a Trinidadian person]". His expression embodies the clear anxiety that some Trinidadians have about Venezuelans entering in larger numbers than authorities presently assess.

Yet, government officials insist that the '40,000' figure is an overestimation. The Prime Minister of Trinidad and Tobago, the honorable Doctor Keith Rowley and other government ministers asserted that the 40,000 number is inflated. They have iterated that the number is widely cited in global media as a result of coercion by global powers to justify intervention in the affairs of a small island nation.

The Prime Minister explained: "Because the larger the number, the bigger role they get to play in your country, by inflating the numbers they could put pressure on the government to do certain things...I have been approached by external forces, external agencies to open refugee camps in Trinidad for Venezuelans...I have flatly refused... those are doors once you open them, they are very difficult to close" (Christopher 2019).

Despite the government's stance that they will help those they can within the limits of the small island state economy, Amnesty International criticized Trinidad for not having any laws to protect asylum-seekers in keeping with international standards and for deporting several Venezuelans (Monitor 2019). "In the face of massive human rights violations in Venezuela, that may amount to crimes against humanity, we have called on states across the Latin America and Caribbean region to take shared responsibility for providing unrestricted access to international systems of protection, such as refugee status, and to expedite access for Venezuelans to legal residency with appropriate safeguards" (Rosas 2019). No mention was made in 
terms of the limits of small island states. Government officials, in Trinidad, therefore, insisted that they will not give in to this global pressure considering the small size of the country and its limited resources, which international organizations, have not acknowledged:

"We, a country of 1.3 million and a little piece of land here...Venezuela has a quarter of the continent and 33 million people, we are going to open refugee camps in Trinidad and Tobago, what is our position? And we must apologize for saying no to that? asked the Prime Minister" (Christopher 2019).

From this position, the government has been working in the interest of national security with Trinidad and Tobago's small population and geographic restriction. The government officials seek to avoid a perceived human tsunami through rigorous border control. From their perspective, it is understandable why Trinidad and Tobago as small islands are unable to absorb larger numbers of Venezuelans officially.

Moreover, while it may be convenient for some Venezuelans to flee to Trinidad, the numbers arriving have reduced according to several reports. The Minister of National Security of Trinidad and Tobago, Stuart Young reported during June 2019 that Venezuelans are no longer, if they ever were, coming to Trinidad "in boatloads" (Neaves 2019). The number of Venezuelans arriving in Trinidad has certainly decreased due to more rigorous border controls and the use of technology to monitor the coastal areas and keep track of arrivals at sea (ibid).

Staff at the Centre for Refugees and Asylum-seekers I spoke to also noted that fewer Venezuelans were registering by August 2019 through the UNHCR after the peak years 2015-2019. They noted, particularly after the 2 week Amnesty Period offered by the government, there was a decrease in numbers.

As one of the staff members, a protection assistant, who worked at the center for 3 years told me, the numbers were certainly declining. She said, "There are two offices for UNHCR registration in Trinidad, one in Port of Spain and one in San Fernando. At one time [2018], I used to have to go down South, to San Fernando, to help because of the vast number of people coming." A deep concern came across her face, referring to Venezuelan migrants, she explained: "They haven't been coming to register like they were in February [2019], I don't know if that means the situation is improving for Venezuelans or it means they are not registering because of the new government policies implemented after the Amnesty period."

This statement suggested that there was a clear reduction in numbers since the protection assistant no longer had to go to the second center. It also points to the uncertainty of whether the visa policy and government registration were progressive or counterproductive for Venezuelans who need assistance.

Despite the uncertainty around the number of undocumented Venezuelan migrants in Trinidad, certainly, during an amnesty period of 2 weeks in June 2019, the government of Trinidad and Tobago officially registered 16,532 Venezuelan migrants and gave them rights to work in Trinidad for 1 year. Thousands gained the right to work, move freely and legally avoid deportation. There are also roughly 12, 685 registered asylum-seekers (UNHCR DATA 2019). Where the UNHCR data intersects with government registration is unknown. 
Trinidad updated its migration policies for Venezuelan migrants after granting the period of the amnesty. They implemented a new policy requiring visas from Venezuelan travelers. If 'Venes' want to stay in Trinidad and Tobago, they must presently register for visas in Caracas, a restriction that did not exist before. Since the amnesty period, 1932 visas have been granted (Lindo et al. 2019).

This conflict between Trinidad and Tobago's government and international organizations which have not been detailed in any academic work to date highlights precisely the problem with large scale migration, international law and local government's interest. "The treatment accorded by a state to its subjects, including the conferment or deprivation of nationality, is a matter of purely domestic concern but there is some authority for the proposition that even this comes within the ambit of international law when the treatment in question offends against those principles of justice and humanity which are recognized by civilized nations" (Jennings 1939: 110). Feldman (2012) also highlights that compassion and obligation is underscored in humanitarianism. Yet, there are challenges between international systems and humanitarian law in light of government authority and state control where state policy generally remains more important than internationally recognized humanitarian regimes (ibid.) In this way, the government maintains that while they cannot accept all asylum-seekers, the government of Trinidad and Tobago has done more than any other country on a per capita basis in its granting of Amnesty for thousands (Neaves et al. 2019). The threat of deportation before the amnesty period was evident since the government maintained that it would not uphold unrestricted international law protecting asylum-seekers from deportation.

Given this background, the dichotomous relationship between international refugee law and local government policy and practice will be explored in the present study by the theoretical analysis of the categorization and lived experiences of some Venezuelans living in Trinidad in the 21 st Century. The fieldwork aims to find out from Venezuelans themselves, why they came to Trinidad, how they came to Trinidad, what status were they given thus far, any discrimination they experienced and what are their sentiments about their experience in registering with UNHCR and/or the government of Trinidad and Tobago.

\section{Methodology}

Interviews and participant observation were done in the waiting room of the office of the UNHCR in Port of Spain, Trinidad.

The surveys had a quantitative approach as measurable data allowed for the generation of statistics from the questionnaires (See Appendix Blank Questionnaire with English Translation). This was advantageous as questionnaires targeted a wide range and number of people in a relatively short amount of time. People who did the questionnaires were also spoken to informally in casual interviews generating anthropological styled data i.e. stories and quoted remarks. The participant observation aspect of the bureaucratic processing of migrants additionally generated qualitative descriptions of events and processes at the centre. This was mostly omitted from this report due to the final angle of the analysis. 
In the questionnaire, there were 25 questions, 3 open-ended questions and 22 closed-ended questions of various types focusing on the pathways which migrants took to enter Trinidad, their motivation for leaving Venezuela, the support they felt in Trinidad and their legal processing by UNHCR and the government of Trinidad and Tobago. The casual interviews were done spontaneously when the questions in the survey stimulated further conversation for as long as the participant wanted, or for as long as they were available before their meeting with the protection assistants. Most respondents gave further details and launched into personal stories easily.

The sample size was 33 people in the process of registering as refugees or asylum seekers at the Ministry. A random selection was done based on who was available for the interview in the waiting area and was willing to have conversations. There was no gender bias as both males and females were included. Their age range was 16-58 and written consent was taken from each participant. Their identity was anonymized by changing their names to generic ones in this final report.

The time constraints under which this research was conducted was a limitation to some degree, 1.5 months of fieldwork in Trinidad mid-June-August 2019 with August-November 2019 initial write-up period. Further analysis and updates were done between January 2020 up to October 2021. The background work of the study also depended heavily on local news and media depictions of the amnesty registration process since it was impossible to be there in person during June 2019 when the registration took place.

Recordings were also unattainable as those who were being interviewed preferred not to have their voices recorded. Given the vulnerability of those involved, fear of potential deportation, and the lack of ethical consent, recordings were not taken. Notes on questionnaire papers and phones were, therefore, the only physical evidence generated from the study.

The interviews were conducted in Spanish mostly which was a very minor limitation. Since I studied Spanish for 7 years at school and I received an advanced level certificate at A-levels for Spanish, I was comfortable discussing in Spanish. However, the language barrier could still be considered a minor limitation as there were a few times questions were repeated to get further clarification on translated answers.

\section{Results and discussion}

\section{Why do 'Venes' come to Trinidad?}

Generally from my respondents, the main reason that migrants from Venezuela seek asylum is due to the downfall of the Venezuelan economy, a public crisis affecting their private lives to a large extent. This forced them to migrate in search of better livelihoods and quality of life (see Table 1. Background 1 and Table 2. Background 2 below for respondents' jobs and address changes and Table 3 Other Brief Notes which are relevant in the following discussions). The public crisis in Venezuela that caused large scale migration was catalysed by a political-economic-social historical context outlined briefly here. The social living conditions of some 33 million Venezuelans were transformed by changes in 


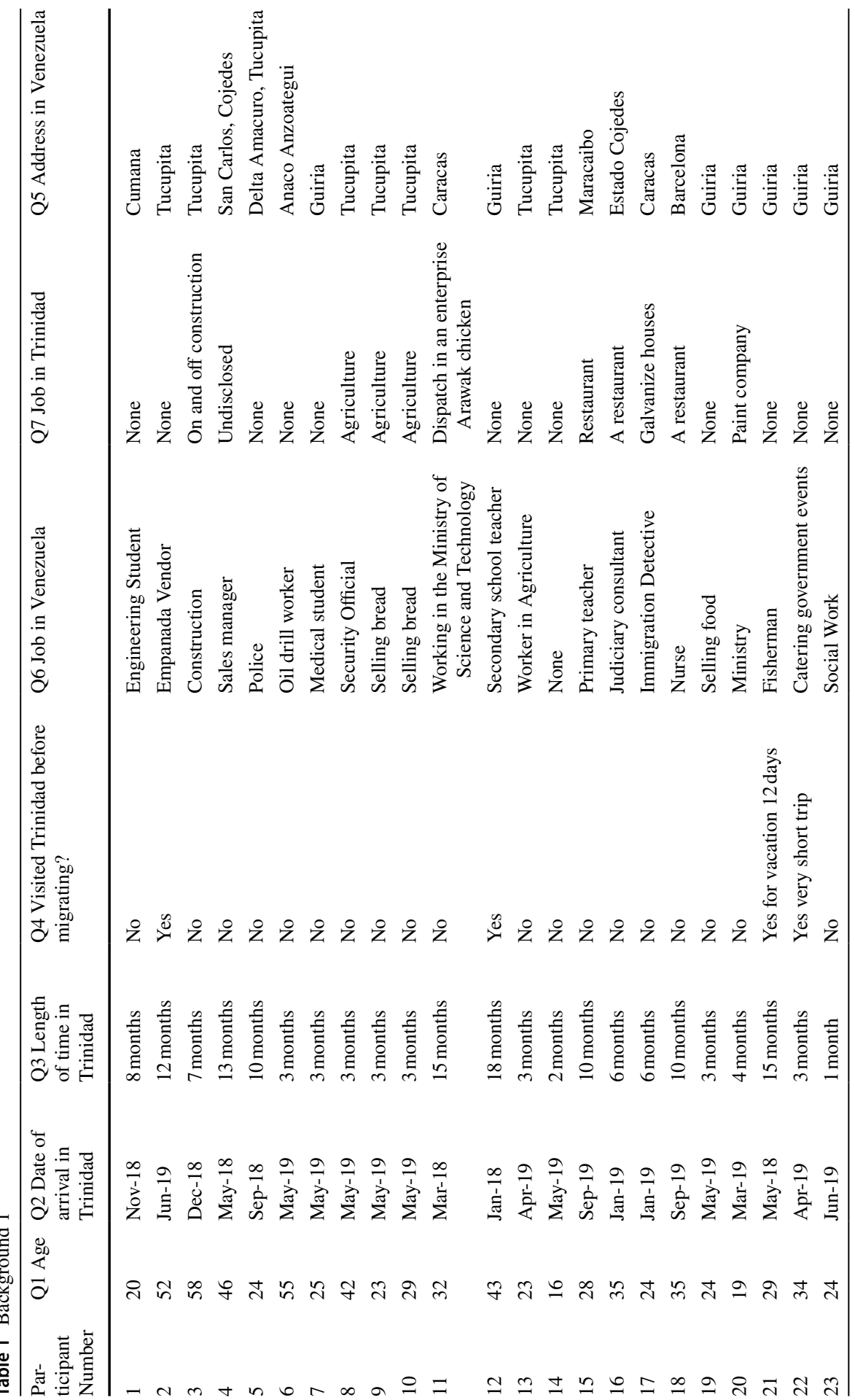




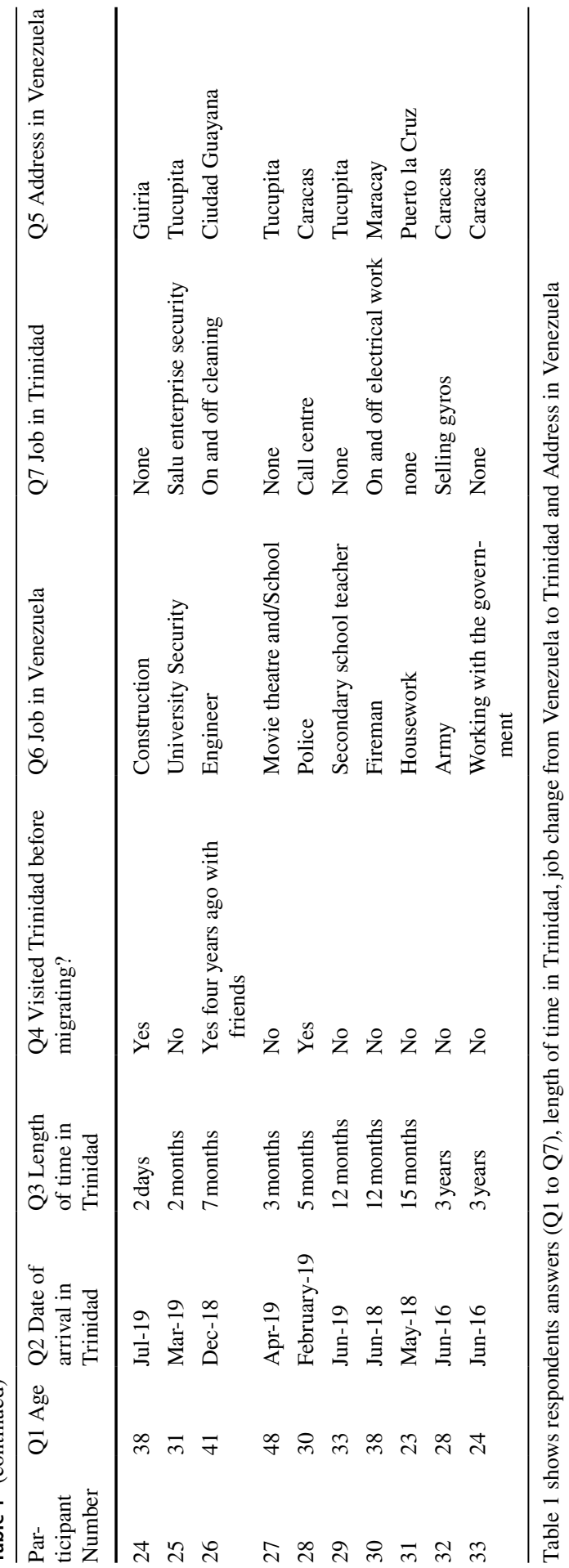




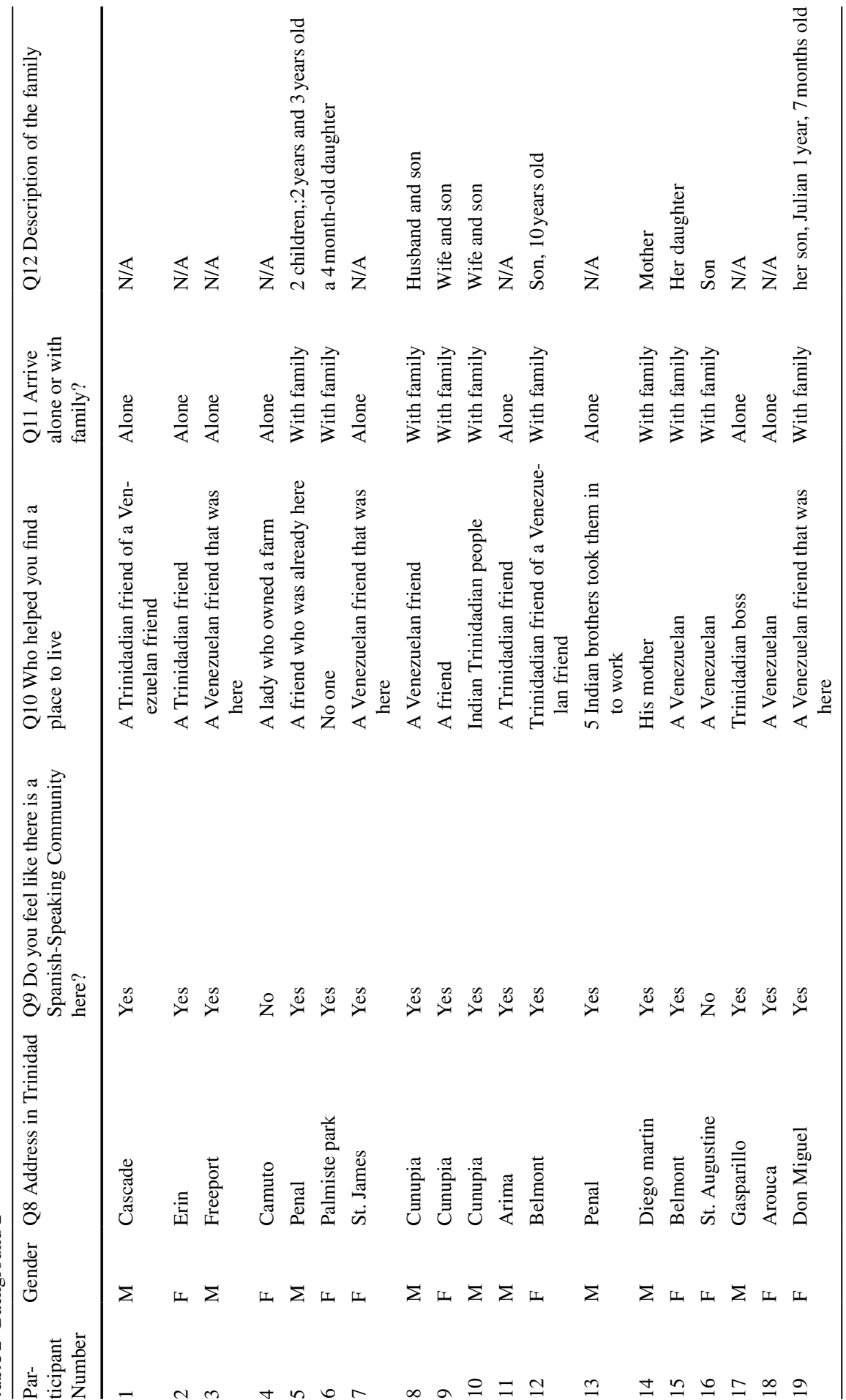




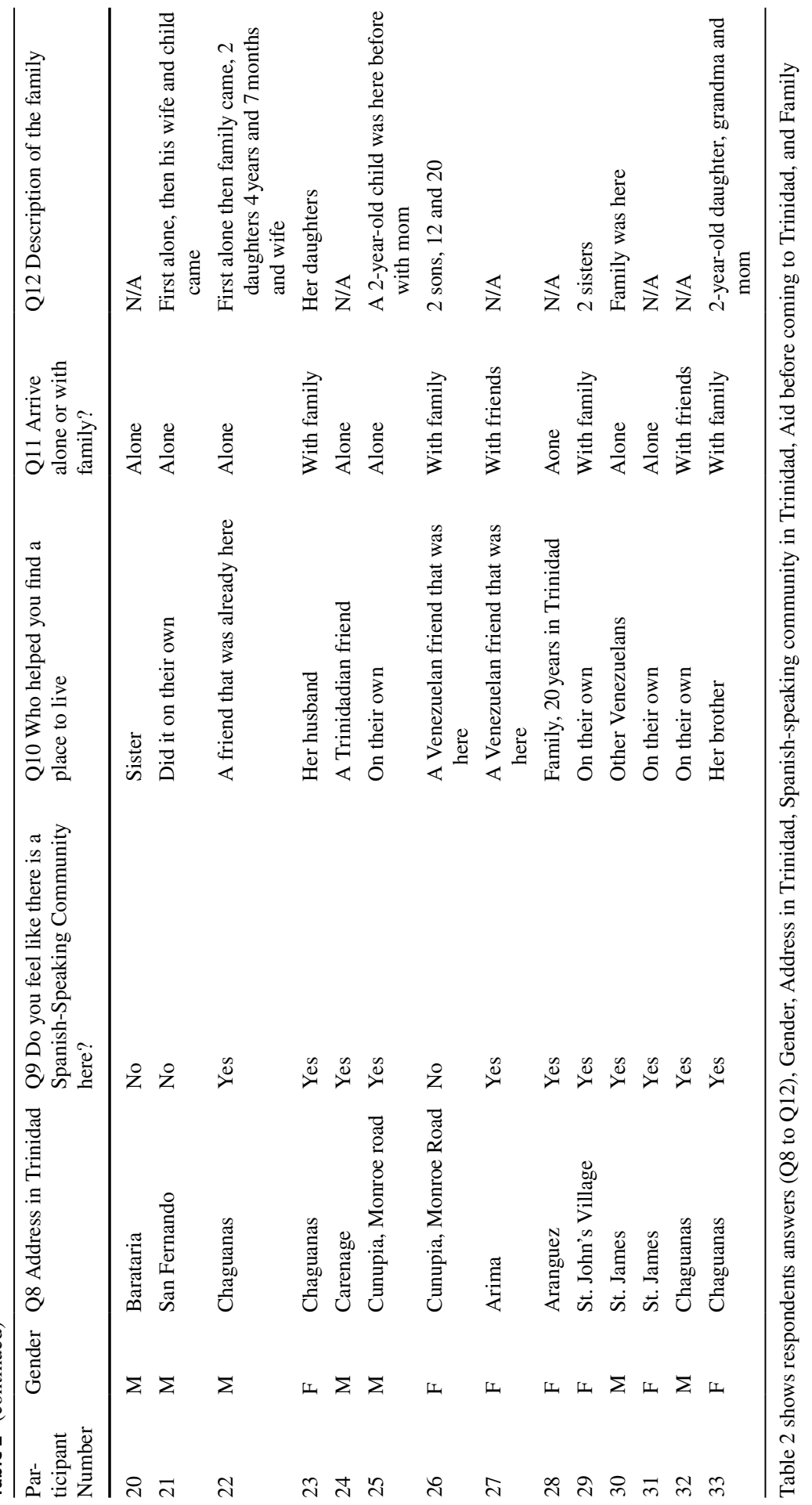


Table 3 Other brief notes

\section{Participant Number Notes (Other Descriptions)}

2

3

4

5

6

7

8

9

10

11

12
The boats were dangerous but we paid so, it was legal.

There are boats back to Venezuela, if you are afraid of getting deported, You can go for a few days and return.

\section{N/A}

I learnt a lot of English here.

Family in Venezuela to return to are on my mind.

A lot of people in Trinidad understand the situation in Venezuela, hunger medicine shortage, not a lot of work is available but people try to help.

N/A

N/A

Bosses help you with a little English.

Some Trinis understand the crisis in Venezuela, others, no.

What if I don't find a place to live or if I will die of hunger were my fears.

Most people think badly of Venezuelans because of misinformation in the media.

There was a really hard situation.

The participant was promised a job to take care of children and the people who she thought were going to help her with work, but they tried to take her somewhere else for prostitution.

The people I know understand the situation in Venezuela, some others don't understand.

Some random Trinis helped organize them after they slept on the street for two days.

The small boat docked in Chaguanas.

\section{N/A}

A lot of people don't understand the crisis.

N/A

More difficult with a child left in Venezuela, her dad worked in a Factory for 15 pesos for the month which could get 2 bags of rice and flour for the month.

\section{N/A}

Family is the only reason he would wish to return to Venezuela.

The situation is really complicated. There are bad and good people in Trinidad.

\section{N/A}

Some people underestimate the situation in the media.

Some people understand, others don't.

This participant was well connected as she has a sibling who was in Trinidad many years before.

N/A

Some people have a negative view of Venezuelans, some people are helpful.

N/A

This participant was in a couple with long stories about apartment rent issues, attempted assault etc.

This participant was in a couple with long stories about apartment rent issues, attempted assault etc.

Table 3 shows other relevant answers summarized 
the economy, in the last 15 years. No doubt, the food shortage in Venezuela was strictly caused by economic inflation and disproportional, military distribution of food for those who support Maduro's regime which left millions without a means of survival (Ellis 2017). The history and politics in Venezuela were beyond the scope of this study but I was able to get some information from respondents about their experience.

The main reason most of my informants said they came to Trinidad was that they simply could not afford to live in Venezuela anymore, could not access basic necessities and felt their work and pay options would be better in Trinidad. Their families did not have enough money or access to food. They felt that they needed to find a way in Trinidad to make money to send back to Venezuela, in order to help themselves and their family members who stayed behind.

Rodriguez, one of my informants, 42 years old, an oil drill worker came to Trinidad with his family (a four-month-old son and his wife). He informed me that the reason they came was that they could not survive in Venezuela. He could not sustain himself and his family with the work he was doing anymore. It simply was not possible to access enough food in his region, Anaco Anzoátegui. As we sat on the concrete steps outside of the LWC center in the Trinidadian heat, he emphasized his hope that he would get help for his family and be able to work in Trinidad. They described that everyone they knew was in a situation of hunger in Venezuela.

Similarly, Mariella, 26, another one of my informants, described the struggle for survival in Venezuela. As we stood on the street just outside the center while she waited for her friend to pick her up, she described that her dad was still back in Venezuela and worked in a factory. With his monthly salary, he could only afford and access 2 bags of rice and 1 bag of flour for the month for a family of five, nothing else. So, she left Venezuela, to try to get work in Trinidad to send money or food back to her family.

The stories of the lack of food and affordable food were salient in the conversations I had at the migrant center. This is the main motivation for categorizing Venezuelans as economic migrants since they are in search of better work, pay, products and livelihoods. Additionally, none of my informants stated that they were fearful for their lives because they were being persecuted.

At the same time, one of my respondents described that as people became more desperate, the situation worsened in terms of crime and violence in their everyday life. There were also electrical outages with worsened the situation. The violent reality in Venezuela is caused by reported social unrest, military action and protests (Ellis 2017). This is specifically important in the context of why Venezuelans flee and can legitimize their status as refugees rather than economic migrants in some capacity.

As mentioned in the literature review, these categories, 'economic migrants' on one side of the coin and 'asylum seeker' or 'refugees' on the other, create the polar framework that when flipped in political debate locally and globally, determines the fate of the people arriving at the shores seeking asylum. The implications of this clear tension between UNHCR policy on asylum-seekers and government policy on 
economic migrants will be evaluated further in the further analysis section and due to the small scale of this study, certainly requires even more research.

In short, the Venezuelans who come to Trinidad according to my respondents, have no choice in their words because, in Venezuela, they are unable to access good work, pay, safety and basic necessities for themselves and their families.

\section{How do'Venes' get to Trinidad?}

The proximity of Venezuela especially regions such as Tucupita makes Trinidad a convenient or rather, less inconvenient location to flee amidst the crisis. Venezuelans can enter Trinidad and Tobago legally by plane/boat or illegally by small boat (pirogue). Until June 2019, Venezuelans were able to travel by plane to Trinidad without a visa for a stay of up to 90 days. This resulted in many migrants who were able to afford the cost of travel, roughly 250 US or more, overstaying their visa and claiming asylum (Surtees 2019). By mid-way 2019, it was no longer possible to come to Trinidad as a Venezuelan by plane without a visa, due to the change in government policy mentioned previously. This change was aimed at reducing the number of Venezuelans entering Trinidad. Currently, it is a requirement for persons from Venezuela to obtain a visa in Caracas to visit or stay in Trinidad and Tobago.

Throughout history, the physical ways in which "refugees" get to their destinations has been dangerous and fear-inducing as highlighted in previous research (Stein 1981; Keller 1975). Despite the closeness of the locations, Venezuelans coming to Trinidad is no exception to this statistic which will be described here. The results from this study highlight that all transport methods for getting to Trinidad involve a certain fear of deportation (see Table 4. Travel Details below for summarized responses). The more illegal the method, the more likely the uncertainty of survival rested on the minds of those who came.

Respondents in the present study who came to Trinidad by plane, 14\% (6 respondents), described the journey as nerve-wracking because of their fear of immigration officers. They all asserted that the immigration officers at the airport treated them with respect and dignity though as they were able to enter Trinidad and claim asylum.

Coming to Trinidad 'illegally' by small boats is the most dangerous. 86\% (27 respondents) in the present research came to Trinidad en bote, a small boat or pirogue. Some described the journey on the water as perilous, paying between 100 USD-250 USD for the journey to Icacos. Even though they were mostly coming 'illegally', all my respondents except for 1 stated that they paid some amount of money. In their various descriptions, the words most often used were terrible, horrible, dangerous, and tiring. Some described it as expensive. Others said dramatic, and traumatic, where they stated they did not want to remember.

From the present study, one of my informants, Bea, a 43- year-old secondary school teacher, described the journey as terrifying. She explained that it took an entire day circling due to Trinidadian coast guard policing even though the journey should take only a few hours. She also detailed that she left her 6-month-old baby with her mother in Venezuela. She ripped up almost all her clothes so that her baby would have "diapers". She came to Trinidad with only a bag of a few personal belongings and was fearful she might not make it. Carlos, 32 who used to work in 


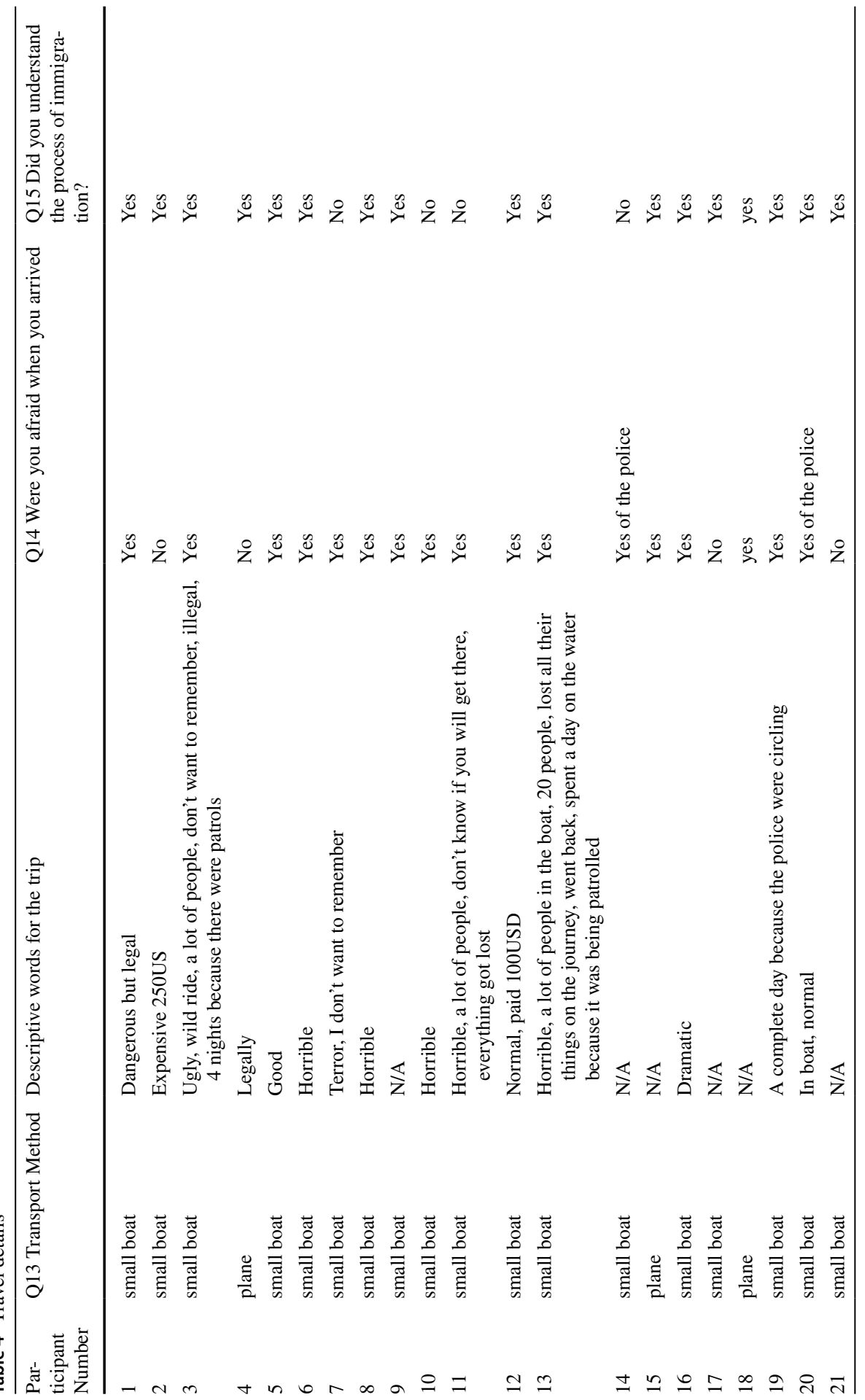




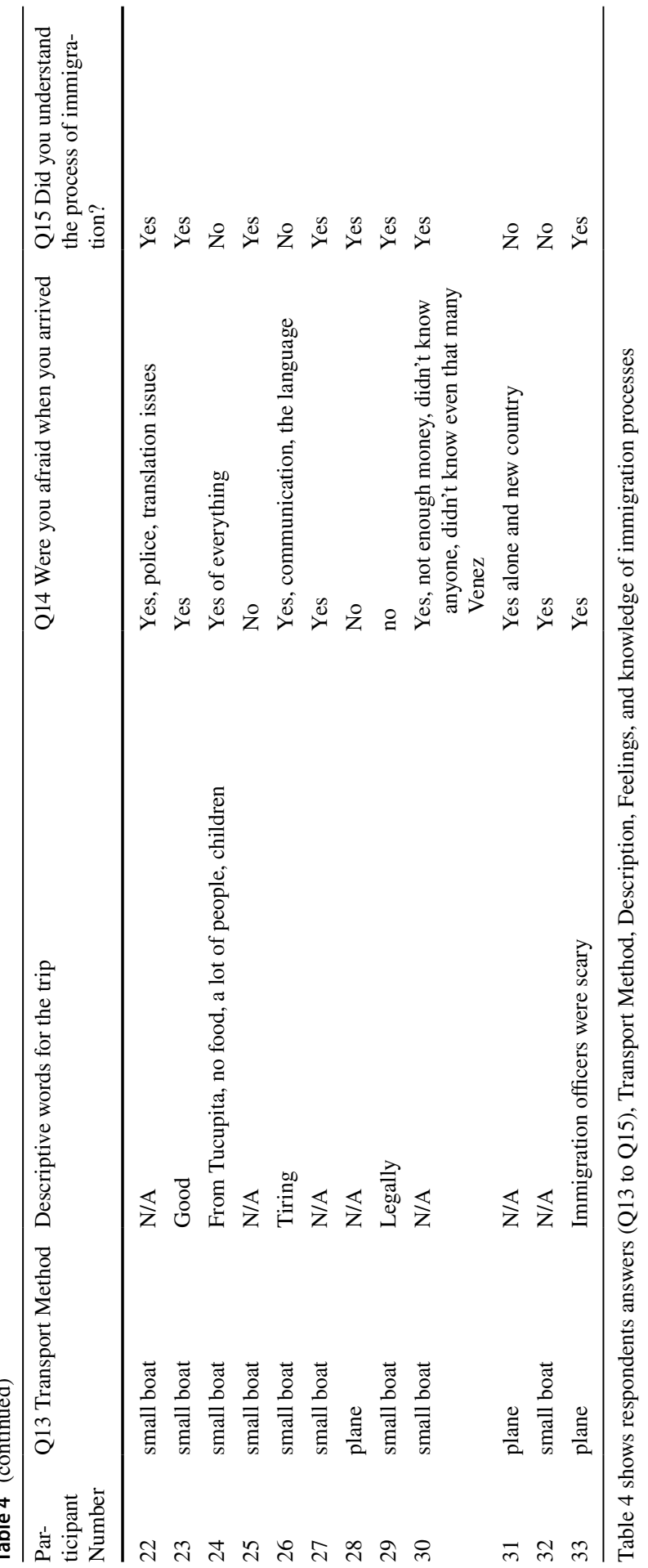


the science ministry in Venezuela told me that he lost everything which he tried to travel with when they were at sea. They also spent more than $18 \mathrm{~h}$ at sea according to his account. He recounted that he was uncertain if they would ever make it ashore to Trinidad while they kept going in different directions. There have been additional reports of missing persons and people drowning on the way to Trinidad in 2019 (Surtees 2019) and even more recently in December 2020 (Douglas et al., 2021). In this light, Venezuelan migrants come by dangerous means if travelling by sea illegally.

\section{What stereotypes and vulnerabilities do Venezuelan migrants face when they get to Trinidad?}

The language barrier and difference in nationality that Venezuelans embody in Trinidad is the central discomfort expressed by Venezuelans in the current study (see Table 5. Support or Discrimination below for summarized responses). There is a certain kind of xenophobia that has been reported by Venezuelans. Maria, 28, who was a primary school teacher in Venezuela, and an employee at Church's Chicken in Trinidad described her struggle at work. She iterated that she had a difficult time because people do not understand or accept Spanish speakers. "They don't want us to take their jobs," she repeated. "They don't like us because we are Spanish," she noted. Approximately 50\% of my informants stated that they had experienced some form of discrimination in Trinidad. Apart from 2 informants who described criminal offences and discrimination i.e. attempted rape and attempted prostitution, which will be detailed below, the majority described verbal abuse and microaggression. The reasons for discrimination, given by informants in the present study who said they experienced disrespect by some Trinidadian people included being culturally different, light-skinned, being different in nationality, the situation in Venezuela, and/or the fact that they spoke no English or mostly spoke Spanish.

Additionally, one of my informants stated that she found the discrimination surprising given that she had interacted with Trinidadians who moved to Venezuela in her neighborhood before coming to Trinidad. She stated that she did not expect such a harsh welcome when she believed that Venezuelans do not respond to Trinidadians that way when they were previously received in Venezuela.

This result is anticipated since it is the first large-scale migration happening in Trinidad in recent years and the language distinction is so profound. More work must be done to mitigate the negative effect of this distinction as highlighted by Teff (2019). It must be noted here that while 16 of the 33 respondents, did say they experienced first-hand discrimination as described, most agreed and made the point that not all Trinidadians felt negative about Venezuelans. Still, the microaggression due to the language barrier is apparent to some degree and is the first stereotypical challenge a migrant likely encounters.

Another stereotype Venezuelans may encounter in Trinidad is the Venezuelan prostitute stereotype. Spanish women from neighboring islands have been cited as particularly vulnerable to illegal trafficking and exploitation in a report on prostitution in the islands. "In Trinidad and Tobago, women and girls from the 


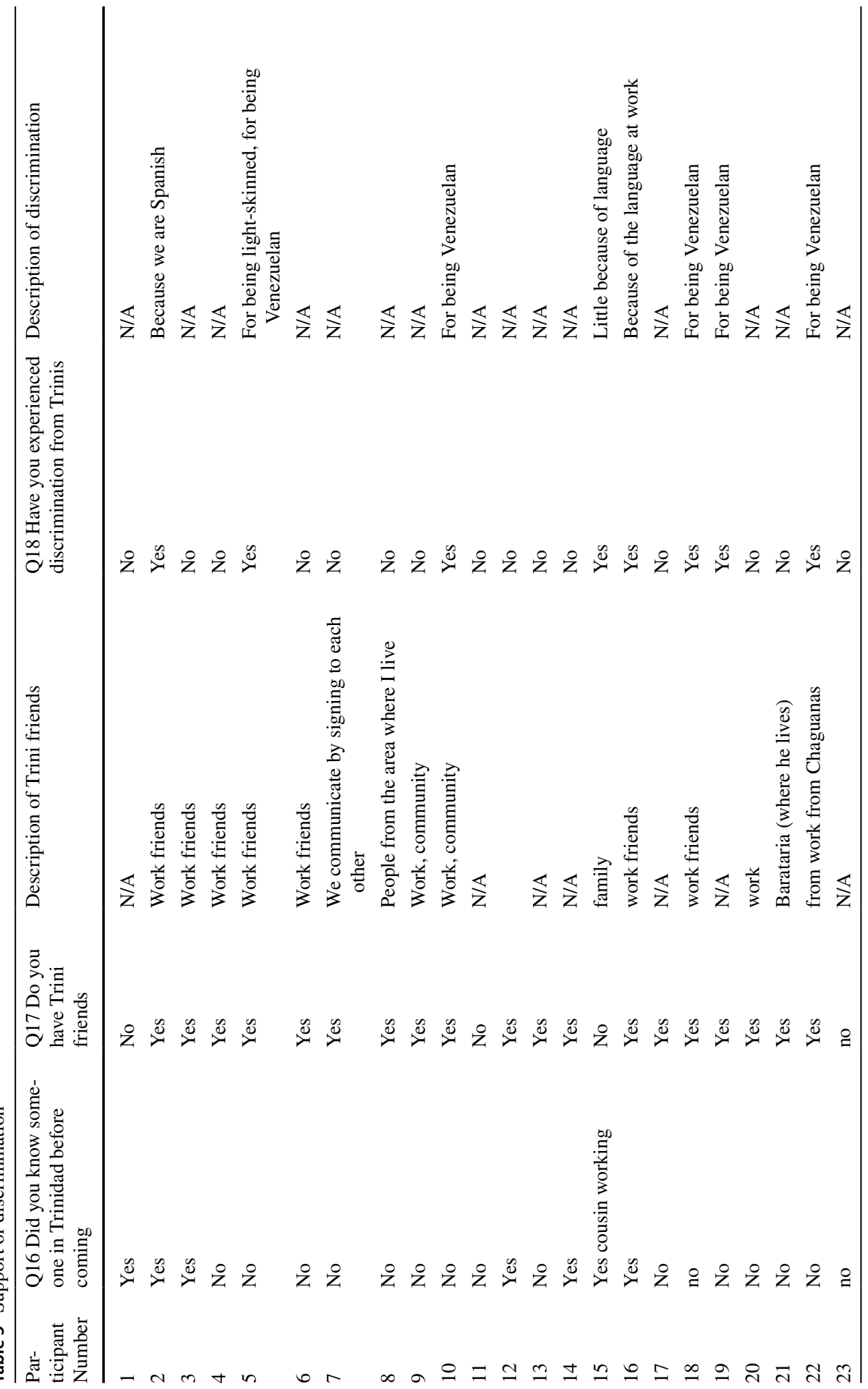




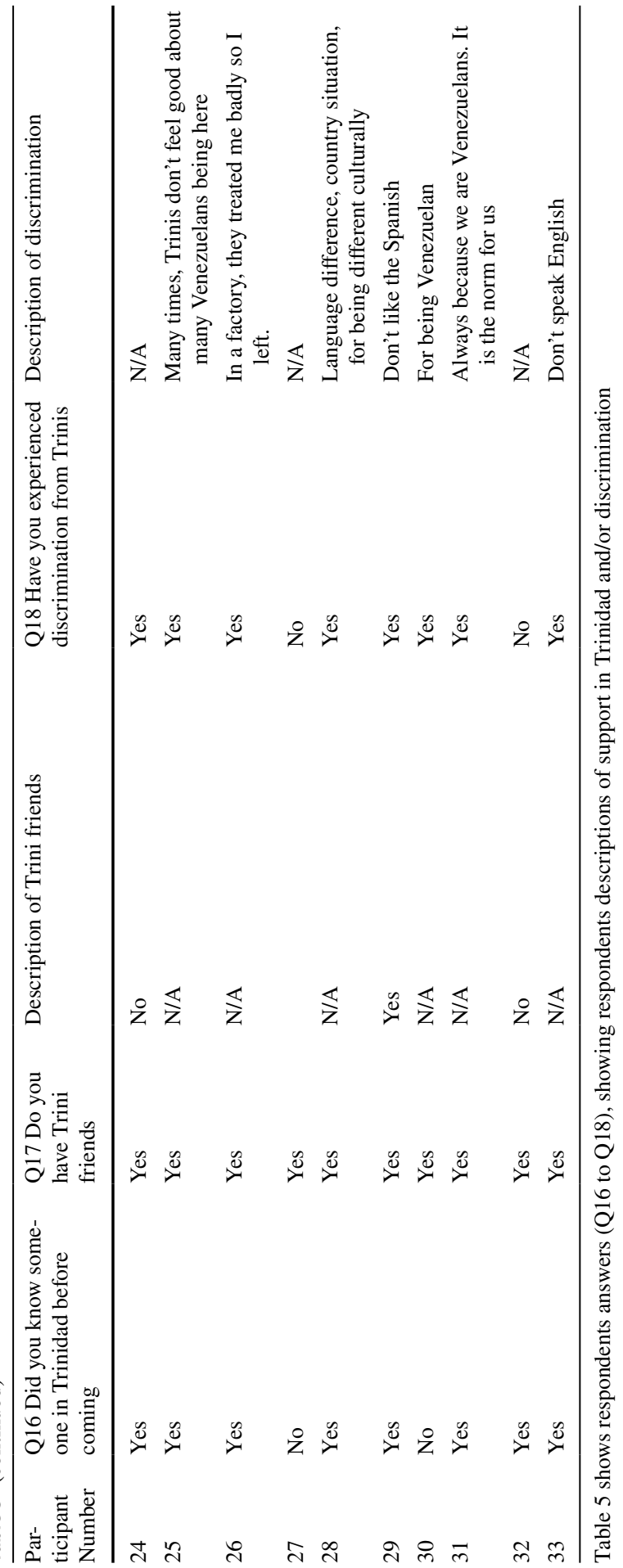


Dominican Republic, Guyana, Venezuela, and Colombia are subjected to sex trafficking in brothels and clubs, often lured by offers of legitimate employment, with young women from Venezuela especially vulnerable" (U.S. Department of State 2019). For Venezuelan women arriving presently, in a different context of forced migration, they may confront a sexualized stereotype to varying degrees.

Margarita, 36 described to me that she was offered work to take care of a Trinidadian woman's children but was taken to a prostitution house. Luckily, she was able to escape, get back to the main road where she got a taxi out of the situation before anything grave happened. She emphasized that if she did not know the area already, or did not have any sense, she would have been trafficked.

Luisa, 24 from Caracas who came to Trinidad in 2016, described that she was a victim of attempted sexual assault about a year after coming to Trinidad by small boat. When she came, this was at the time when Venezuelans could enter Trinidad without a visa. She disclosed that one day, she encountered her worst nightmare while taking a taxi from central Trinidad, Chaguanas to Port of Spain, Trinidad. In her words, the taxi driver took her down a quiet road. He pulled out a gun in one hand and told her to take off her top. She described her horror and shock when she realized the danger. She told me this disturbing tale, amidst the silence of the UNHCR office where she was seeking emergency aid for a rent issue. She continued by telling me of her screaming, crying and pleading with him not to make her do what he requested. He insisted and told her the words which haunt her still today, "You can't do anything but what I want, I could take you in the mountains and chop you up, no one would know or care because you are illegal, your family won't be able to find you and the police here won't even look for you." She reflected, saying that she does not know how but his words provoked her to grab the steering wheel and shake the vehicle onto the shoulder of the road. With her dangerous maneuver, he stopped the car, while she was screaming in Spanish that she would kill them both. She ran out, tears streaming down her face and he sped off. Her shirt ripped and her mind on her narrow escape, she stood at the side of the highway, traumatized. A local citizen picked her up and took her to the police station. Luckily, she was taken seriously by the police. Within months, the man was found and charged with attempted sexual assault. From the story detailed here, the words of the taxi driver embody the most common manifestation of vulnerability experienced by displaced people, i.e. the vulnerability to exploitation and the insecurity of legal protection.

Historically, women unable to gain legal status or employment are more vulnerable to exploitation which is an important aspect of the lived experience for displaced people, specifically women. At the time of the horrible incident, Luisa did not have a legal status in Trinidad making her more vulnerable. This was also when the legal ambiguity of Venezuelans was higher than at present due to the government constitution. As described by the refugee's international report on sexual exploitation of Venezuelans, the risk of women and girls being trafficked and exploited are higher in conditions where safe and legal pathways of entry are not maintained in the host country, where legal rights are not granted so reporting to authorities is diminished, and places where the right to work is not granted (Teff 2019). Presently, the 
Counter-Trafficking Unit, the Living Waters community and the government aim to protect and support Venezuelan women to mitigate such exploitation.

Furthermore, while these stereotypes and stigma exist, and disturbing cases such as Margarita and Luisa's are reported, not every migrant experiences discrimination or exploitation to the same extent. Half of my informants claimed that no significant discrimination of their knowledge had occurred since their arrival in Trinidad, with a disproportionate number being men (10 out of 17). Even so, most agreed that navigating Trinidadian society was difficult at times due to the language barrier. In general, Trinidadians are not always malicious towards Venezuelans based on views expressed by informants.

\section{What status do Venezuelans have in Trinidad?}

Most of the respondents had not gained "refugee" or official "asylum seeker" status (see Table 6. Government Registration, Legal status and Aid above). Although they were likely to get it in due time, the value of it in terms of the right to work and move freely without deportation remained a cause for concern in the discussions. This will be analyzed in the further analysis section. Considering this limiting characterization of the refugee in migrant processing, a gross minority of the people I spoke to had officially gained UNHCR 'refugee' status (2 out of 33 people). The ones that did, said that it took 2 years. During that time, they were fearful of being deported until they were government registered. Many of the respondents were in the process of gaining 'asylum seeker' rights and were categorized as 'de facto asylum-seekers'.

Additionally, more than half of the respondents said that they were afraid of being deported despite arriving safely and being processed. From the discussions, this was due to the anxiety around police ignoring asylum seeker rights and documentation and following government orders to detain or deport "illegal" persons.

\section{Further analysis}

\section{The unstable 'refugee': a political identity, a contrived label or an actual person?}

Spending time at the LWC center for refugees and asylum-seekers, I learned very quickly that meeting and talking to Venezuelan 'refugees' was not meeting people who identified as refugees but who were complex individuals; ordinary people, albeit displaced ones, who were in a process of negotiation; becoming a refugee. There is extensive empirical evidence to illustrate that refugees conceive their identity in very different terms from those bestowing the label (Harrell-Bond and Voutira 1992; Mazur 1989; Zetter 1991). Individuals do not fit entirely into the presumed identity of a refugee. Individuals' identities and circumstances that manifest around them: social, economic, and political remain complex through time and space. Their needs, and desires for freedom, legitimization, and happiness can get lost in a world of categories, deservingness, nationality dissonance, and power politics. 
International Journal of Anthropology and Ethnology

(2021) $5: 15$

Page 23 of 33

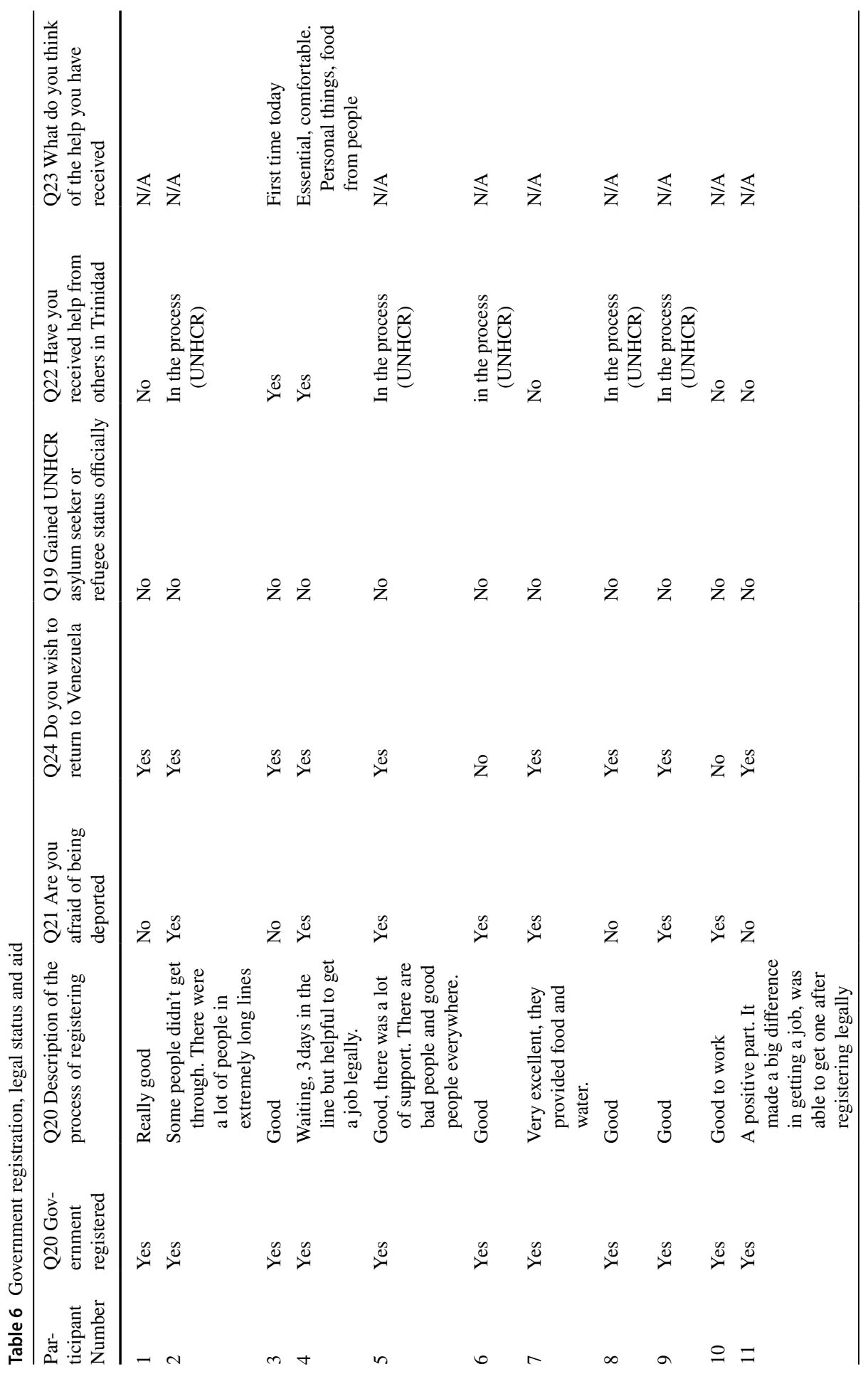

Springer Open 


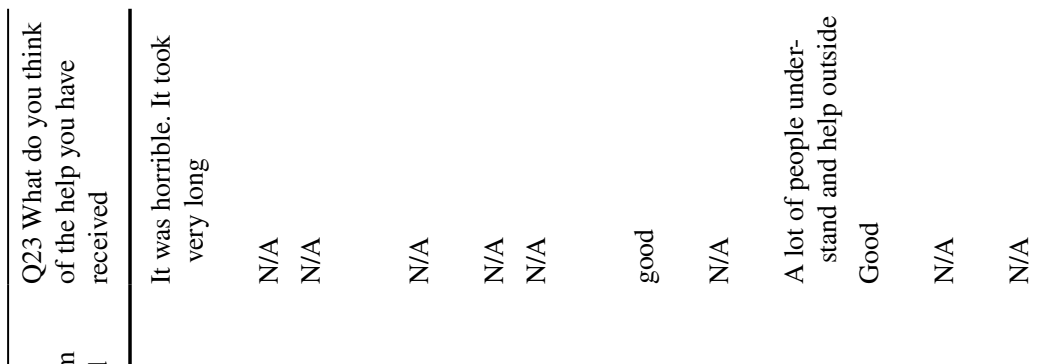

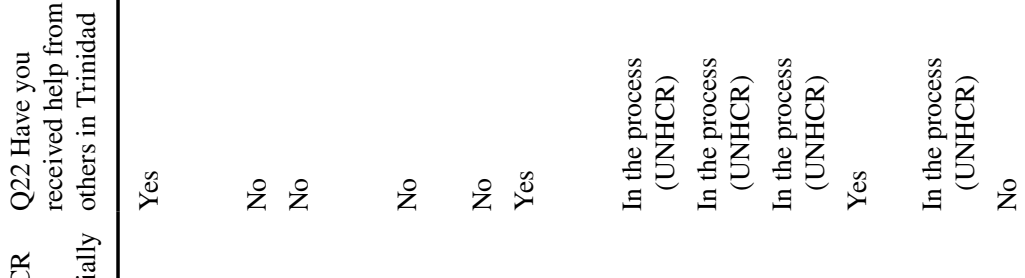

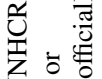

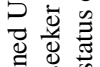

范萬范

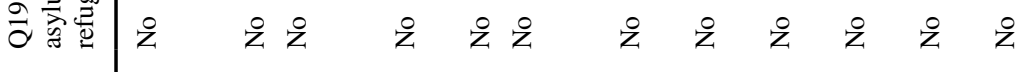

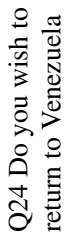

כ.

至范总

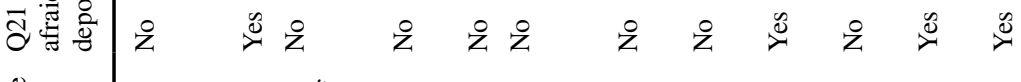

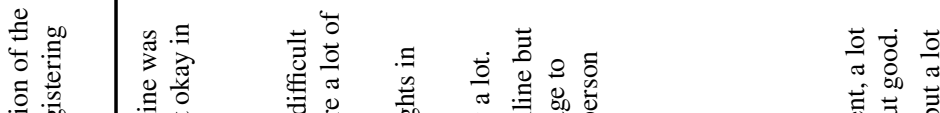

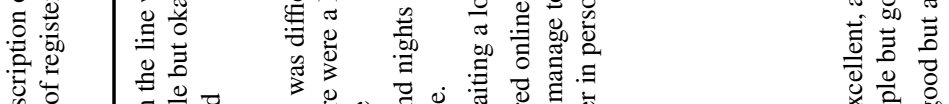

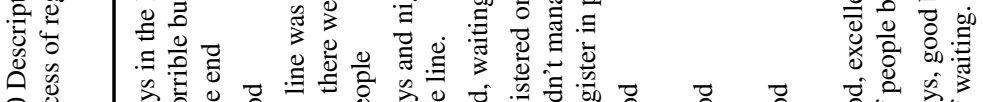

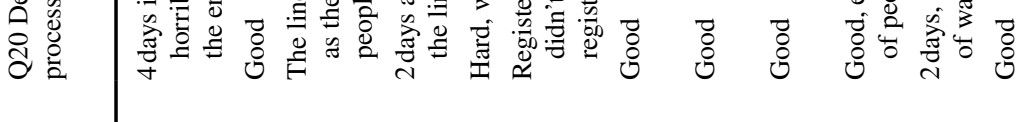

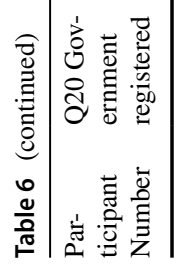

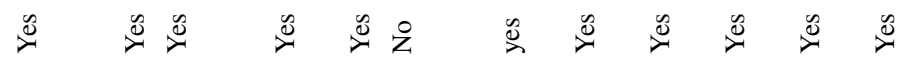

ㅃำำ 


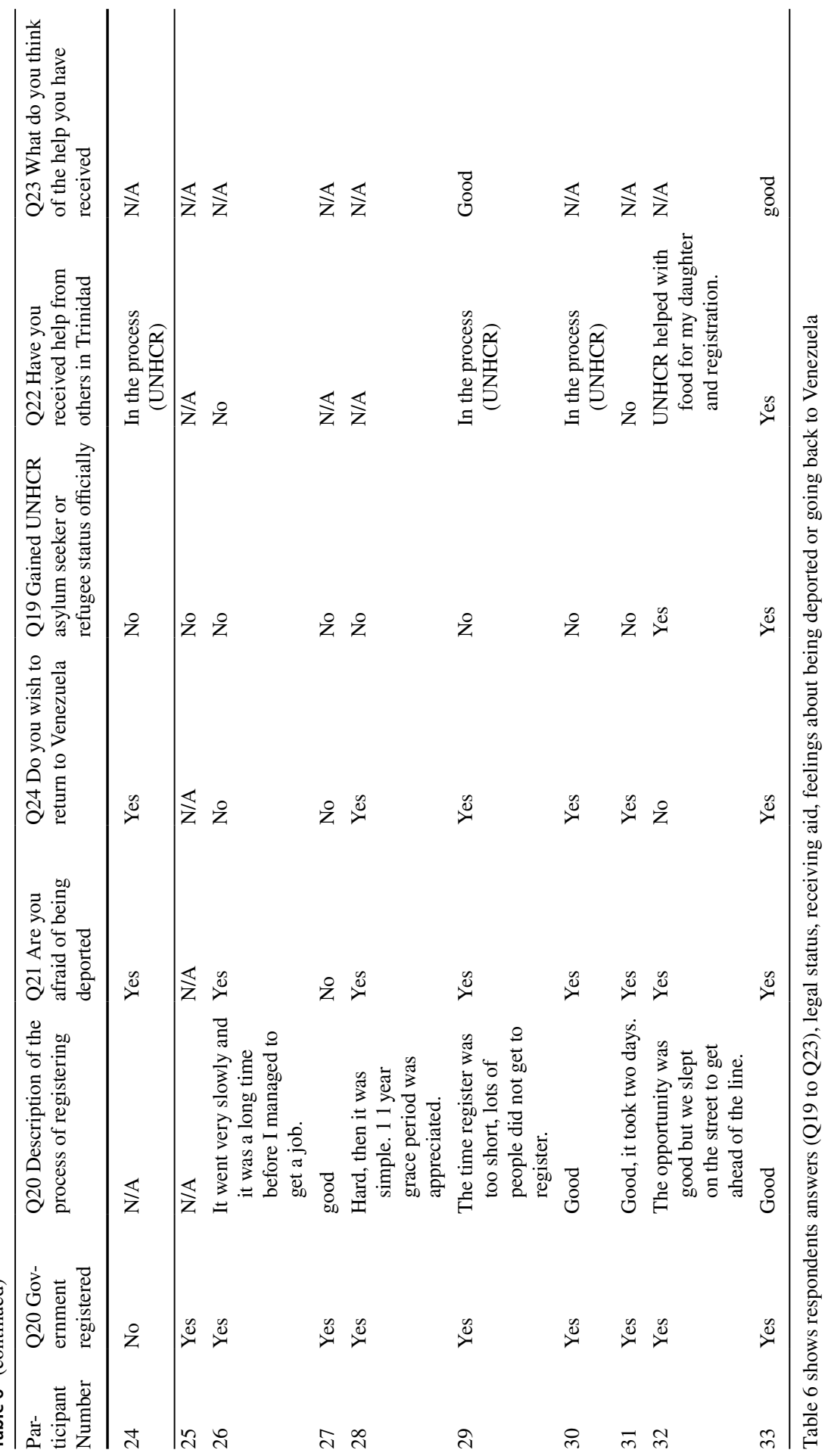


The UNHCR 'refugee' definition excludes economic migrant cases to a large extent making the seemingly clear-cut political identity a highly contrived label. Economic reasons are secondary and less legitimate in the process of gaining refugee status (Teff 2017). "Lacking the evidence of clear-cut war and sudden mass exodus, which often gave legitimacy to the label 'refugee' in the past, is now much harder for these forced migrants to assert persecution and flight in fear of their lives" (Zetter 2007: 178). Zetter's claims fit perfectly into the present analysis since this is precisely the case with Venezuelan migrants in Trinidad. Thus, the refugee label in practice remains implicated in why some people affected by forced migration are unable to securely gain rights.

Moreover, the rights of the asylum seeker and refugee are constrained when one considers the needs and desires of displaced people. Asylum-seeker rights, when upheld, only guarantee non-refoulment and are dependent on nation-states and law enforcement to uphold this right. Refugee status itself once acquired, only ensures three rights in practice - (1) not to be deported, (2) free movement, and (3) family reunification (Teff 2019). This means that those who gained government protection, such as in the registration done by Trinidad and Tobago's government, improved their conditions better than with UNHCR's refugee or asylum-seeker status. This point has gone under the radar in international coverage of the issue. As highlighted in the first result section, Venezuelan migrants emphasized their desire to work in Trinidad to survive, their central motivator for migration. Therefore, since the categorization involved in international protection does not ensure that migrants gain work which is the aid they are seeking, the status remains less valuable.

The government responses remain important to the legality and rights gained in policy and practice by 'irregular' migrants. From the point of view of the limitations of small island states, Trinidad and Tobago's immigration laws do not undermine the empathy and aid sought by Venezuelan migrants, given the size of the country and the limits of the capacity of the island. Those who were able to gain government papers were overall appreciative since they really could not be deported with those papers. Most of my respondents described the initiative by the government as 'good' while they empathized with those who were unable to register (See Table 6. Government Registration, Legal Status and Aid). In this light, the situation is more complex than the government outright denying asylum-seekers rights which I suggest here should be taken into account in international law and by foreign agencies.

Furthermore, more work needs to be done in terms of centralizing the needs of displaced people in general. There is no one way of categorizing displaced people and their needs. However, certain requirements remain cross-culturally applicable as the results indicate and must be emphasized. From the above discussion, Venezuelan "refugees" are people who need jobs and access to food, water and shelter like all people the world over do, in order to sustain themselves and their families. The respondents' central concern based on the presented data, was their basic survival, finances, potential to flourish in families, to create "good" lives, and to be part of a society that acknowledged them legally and socially [to a lesser extent]. Thus, the needs of "refugees" emphasize the way that all legal efforts to gain rights and status are more symptomatic and technocratic results of a central desire for human survival. 
In line with previous research, this study suggests that more can be done to help migrants outside of these categories and processing aid. As Malkki (1995) points out that rather than providing immediate emergency relief, the foreign agencies involved should also concentrate on setting up mechanisms for long term development aid to improve conditions of life for everyone in impoverished regions of the Third World who are disproportionately displaced in the unequal world order. More developmental studies should foreground the global, political, historical process that generates a given group of refugees (ibid.)

Lastly, complex ethical questions have been asked of the humanitarian regime precisely because the refugees they assist do not always conveniently conform to the image of the label (Andersson 2014). Who are the 'real' refugees (conforming to an image of victims?) and who is being protected? In complex emergencies, many people are caught up in conflict and flee, though they are not persecuted as exemplified in the present study. Thus, some final questions arise, who must take responsibility for the lives of those experiencing forced migration? The international organizations look to governments, yet the governments, especially small ones such as Trinidad, look at the international political and economic landscape with their hands tied to a certain degree. Where does that leave the actual people "forced into illegality"?

\section{Gratitude and empathy towards an anthropology of the 'good' and lived experiences}

Anthropology and perhaps social science entirely, has generally developed at present around the suffering subject yet the presence of such work highlights the potential for ways of living better than the ways in which it documents (Robbins 2013). As Robbins (2013) calls for work with "good" construction around the "suffering" subject to enhance ethnography, this part of the further analysis foregrounds the gratitude expressed by informants. The gratitude towards the government embodied by those who registered during the amnesty period in this research brings a positive perspective on governmental efforts to assist Venezuelan migrants. Thirty-one of the 33 people in the present case study registered with the government of Trinidad and Tobago and only 1 person described the process as entirely negative.

While many participants agreed that the effort was good, they also agreed that the logistics of it was imperfect with only three registration points opening throughout Trinidad and Tobago, when 5 was the intention. Moreover, not every Venezuelan that made it to the registration points, were able to register due to the strict time constraints of the two-week period and a large number of Venezuelans coming to register by the thousands.

Still, this was a positive part of the migrant experience in Trinidad where the government granted work rights which was the main desire of the Venezuelan migrants according to those I spoke to at the center. As a suggestion, towards more research beyond the suffering subject, more work can perhaps be done on Venezuelan contributions to Trinidadian society to balance the narratives of illegitimate asylum-seeking since Venezuelan and Trinidad have a long history. 


\section{The importance of lived experiences}

Luisa and her boyfriend Jose, 34, managed to make their way into Trinidadian society for 3 years. Jose worked at a local food truck and Luisa took care of her daughter at home doing temporary work, cleaning, a typical job of migrant women in the present study. A few minutes into the interview, they asked me if I would rather speak in English. Both, having lived in Trinidad for 3 years, learnt English almost to native level capacity, a reality that was both impressive and inspiring. They were the only two informants who spoke English fluently, they had been in Trinidad the longest, gained refugee status and undertook government registration. Luisa shared many stories with me, about the difficulty of finding a job, an apartment, raising her 4-year-old daughter in Trinidad, bringing her much older grandmother to Trinidad from Venezuela, and issues with immigration officers who were called by Trinidadian neighbors under suspicion of their "illegality". This suspicion proved to be false yet Luisa felt it was necessary to share her experience of xenophobia.

Jose got up abruptly after we had been conversing for some time, went out of the waiting room and came back 20 min later. He returned smiling and offered me a Minute Maid orange juice, saying "Thanks for talking to us. I am really glad you are here, because it's a lot, coming here and going through all of this with no one knowing what you really been through and everyone thinking they know what it islike for 'Venes' in Trinidad". His kind words and gesture embody the need for more anthropological research on the lived experience of forced migration as mentioned by Robertson (2018).

\section{Realistic expectations of small island states}

Many amnesty organizations and local NGOs requested that the government of Trinidad and Tobago extend the Amnesty period. I argue here from the size of the island alone, vilifying Trinidad and Tobago for not upholding international law on non-refoulment of asylum-seekers has little substance. While UNHCR embraces the migration management paradigm and is the rightful global police of populations (see Scheel and Ratfisch 2013), how governments handle 'asylum seekers' is a domestic issue. Moreover, Trinidad and Tobago's government maintains that it has done more than any other country on a per capita basis within the limits of time and space, by registering approximately 16,400 migrants.

In this light, the Venezuelan migrant continues to be a source of global and local tension in migration policy, humanitarian responsibility and governmental politics in Trinidad. The depiction of Venezuelan 'refugees' and the frameworks for understanding them, i.e. economic migrant or refugee, are strategically deployed and tell partial stories, that often justify some behaviour, whether that be pressure to absorb them into the society, intervening in the name of human rights or implement more rigorous border control in line with previous research.

At the same time, many Venezuelans remain in need of protection and support whether that be international assistance or other governmental registration in states where it is still possible. More cohesive policymaking and support from 
international organizations are necessary to protect those affected by forced migration. Rather than blame games and disconnected dialogue, a joint response from international and local bodies is suggested here as the only viable solution for mitigating the effects of the crisis on the people forced into illegality categorized as 'de facto asylum seekers'.

\section{Conclusion}

Anthropology has a unique power to contextualize and inform policy since it goes beyond symptoms and solutions to a world where the person as a living, changing complex site can be met with the aid and empathy they seek on their own terms. The way in which economic migrants as a category has been deployed presents a conflict since it is the main opposing category to an 'asylum seeker' or 'refugee' that allows governments to refuse people in need of aid. International organizations, in line with humanitarian obligation and compassion for all 'asylum seekers', reprimanded Trinidad and Tobago as noted above in their detention and deportation of Venezuelan migrants. Yet, no acknowledgement of Trinidad and Tobago's clear geographical and economic restrictions has been made, highlighting a tension between the local and the global presented here.

Moreover, the government's efforts to assist as many Venezuelan migrants as possible within the limits of time and space remains maligned against the backdrop of external powers that seek to "protect the rights of all asylum seekers". At the same time, 'asylum seeker' and refugee' rights and categorization are reasonably difficult to acquire in the stringent nature of the policies and they do not create opportunities and rights to work in reality. Hence, this research emphasizes that for 'asylum seekers' in the Global Southern context presented here, government registration offered a short-term solution with high aid outcomes despite the limits when compared to rights afforded by international UNHCR protection.

By focusing on the migrants' motivations, desires and the worlds they left and enter, we can create environments to better protect and integrate people more effectively in the globalized modern world.

\section{Appendix}

\section{Blank questionnaire with English translation}

Todas las respuestas son completamente anónimas. All responses are anonymous.

1. ¿Cuántos años tienes?

How old are you?

2. ¿Cuándo llegaste a Trinidad?

When did you arrive in Trinidad?

3. ¿Cuánto tiempo hace que has estado en Trinidad?

How long have you been in Trinidad? 
4. ¿Antes de la crisis, has visitado Trinidad? Sí/No

Before the crisis, have you visited Trinidad? Yes/No

5. ¿Dónde viviste en Venezuela?

Where did you live in Venezuela?

6. ¿Cuál fue tu trabajo en Venezuela?

What was your job in Venezuela?

7. ¿Tienes un trabajo en Trinidad?

Do you have a job in Trinidad?

8. ¿Dónde vives en Trinidad?

Where do you live in Trinidad?

9. ¿Piensas que tienes una comunidad hispanohablante en Trinidad? Sí/No

Do you think that you have a spanish-speaking community in Trinidad? Yes/ No

10. ¿Quién te ayudó a encontrar un lugar para vivir en Trinidad?

Who helped you find a place to live in Trinidad?

11. Describe cómo y por qué viniste a Trinidad y Tobago.

Describe how and why you travelled to Trinidad and Tobago.

12. ¿Llegaste a Trinidad solo(a) o con tu familia? solo(a)/con familia?

Did you arrive in Trinidad alone or with family?

13. ¿Llegaste a Trinidad en bote? Si/No ¿Pagaste para ir en bote? Sí/No

Did you arrive in Trinidad by boat? Yes or No Did you pay to go by boat? Yes or No?

14. ¿Tuviste miedo cuando llegaste a Trinidad? Sí/No ¿Y Por qué?

Were you afraid when you arrived in Trinidad? Yes or No, and why?

15. ¿Cuándo llegaste a Trinidad, entendiste el proceso de inmigación? Sí/No

When you arrived in Trinidad, did you understand the immigration process? Yes/No

16. ¿Conociste a alguien en Trinidad antes de venir?

Did you know someone in Trinidad before coming?

17. ¿Tienes amigos Trinitarios? Sí/No

Do you have Trinidadian friends? Yes or No

18. ¿Has experimentado alguna discriminación por parte de los trinitarios? Sí/No

Have you experienced any discrimination by Trinidadians?

19. ¿Tienes el estatus de refugiado o te han dado asilo todavía? Sí/No

Do you have refugee status or have been given asylum yet? Yes or No

20. ¿Se registró con el gobierno de Trinidad durante el período de amnistía en Junio?¿Qué piensas del proceso?

Did you register with the government during the Amnesty period in June? What did you think of the process?

21. ¿Tienes miedo de ser deportado? Sí/No

Are you afraid of being deported? Yes/No.

22. ¿Recibiste alguna ayuda de la comunidad Living Waters o UNHCR o otra persona? $\mathrm{Si} / \mathrm{No}$

Have you received any help from the Living Waters community or UNHCR or another person? Yes/No

23. ¿Quieres volver a Venezuela algun dia? 


\section{Do you want to return to Venezuela someday?}

24. ¿Qué te parece la ayuda que has recibido en Trinidad?

What do you think of the help you have received in Trinidad?

25. ¿Tiene algunas historias que le gustaría compartir conmigo sobre salir de Venezuela o estar en Trinidad?

Do you have any stories you would like to share with me about leaving Venezuela or being in Trinidad?

Supplementary Information The online version contains supplementary material available at https://doi. org/10.1186/s41257-021-00056-3.

Acknowledgements I am indebted to the coordinators at the LWC Ministry for Refugees and Asylum seekers for allowing me access to conduct this research. To the employees at the centre, thank you for answering my sometimes-uncomfortable questions and for being an anchor while I conducted research.

I extend a special thanks to Dr. Aaron Kappeler, my supervisor from The Department of Social Anthropology at The University of Edinburgh, Scotland who encouraged and supported me in the entire process, from stepping onto the field confidently to drafting this document.

To the participants, thank you for sharing your story with me.

Author's contributions This research was conducted as a partial requirement for the degree, M.A. Linguistics and Anthropology at The University of Edinburgh, Scotland, 2019. The author(s) read and approved the final manuscript.

Funding The School of Social and Political Science, University of Edinburgh paid 500 GBP to the researcher to help with the cost of flight to travel to Trinidad and Tobago to conduct the study. The funding body had no role in the creation of the study, collection, analysis, interpretation of data or presentation of results.

Availability of data and materials Data and materials were added as supplementary documents in the submission.

\section{Declarations}

Ethics approval and consent to participate Ethical approval for this study was gained through The University of Edinburgh Ethics review online for the School of Social and Political Science before the study conducted in 2019.

Consent for publication Consent was gained by all participants and data was anonymized in the report.

Competing interests Not Applicable.

Open Access This article is licensed under a Creative Commons Attribution 4.0 International License, which permits use, sharing, adaptation, distribution and reproduction in any medium or format, as long as you give appropriate credit to the original author(s) and the source, provide a link to the Creative Commons licence, and indicate if changes were made. The images or other third party material in this article are included in the article's Creative Commons licence, unless indicated otherwise in a credit line to the material. If material is not included in the article's Creative Commons licence and your intended use is not permitted by statutory regulation or exceeds the permitted use, you will need to obtain permission directly from the copyright holder. To view a copy of this licence, visit http://creativecommons.org/licen ses/by/4.0/. 


\section{References}

Andersson, R. 2014. Illegality Inc.: Clandestine migration and the business of bordering Europe. Berkeley: University of California Press.

BBC News. 2019. The displaced: When 40,000 desperate Venezuelans hit a tiny island. BBC News YouTube. Available at: https://www.youtube.com/watch?v=vhVFJiieZ6I. Accessed 29 Oct 2019.

Christopher, P. (2019). PM: No Venezuelan refugee camp here. Available at: http://www.guardian. co.tt/news/pm-no-venezuelan-refugee-camp-here6.2.819522.e406be8ac5?fbclid=IwAR2RIv1H Cz2-4Uu0HOdTk5Ycs_eV_8BXeBg7Lgi3KPQ7bn_iFTh8yUSBtmw. Accessed 22 Oct 2019.

De Silva, K. 2019. Venezuelans hide in the forest; feed on mangoes, coconuts. Guardian.co.tt Available at: http://www.guardian.co.tt/news/venezuelans-hide-in-forest-feedon-mangoes-coconuts-6. 2.852575.f95e929326. Accessed 28 Oct 2019.

Department of State. (2019). Trinidad and Tobago. Available at: https://web.archive.org/web/20170 703181538/https://www.state.gov/j/tip/rls/tiprpt/countries/2017/271301.htm. Accessed 20 Oct 2019.

Douglas, S., Lindo, P., Vende, J., Gonzales, E., Hing, K., Doughty, M., Gioannetti, A., Kenzie, R., Superville, S. and Loutoo, J., 2021. [UPDATED] TT STILL BLAMED FOR TRAGEDY - Trinidad and Tobago Newsday. [online] Trinidad and Tobago Newsday. Available at: https://newsday.co. tt/2021/01/05/govt-oas-tarnishing-tt-over-venezuelan-drowning-tragedy.

Ellis, E. 2017. The collapse of Venezuela and its impact on the region. Military Review 97 (4): 22.

Feldman, I. 2012. The humanitarian condition: Palestinian refugees and the politics of living. Humanity: An International Journal of Human Rights, Humanitarianism \& Development 3 (2): 155172.

Goodman, S., and S. Speer. 2007. Category use in the construction of asylum seekers. Critical Discourse Studies 4 (2): 165-185.

Harrell-Bond, B., and E. Voutira. 1992. Anthropology and the study of refugees. Anthropology Today 8 (4): 6 .

International Organization for Migration. 2021. Refugees and migrants from Venezuela top four million. IOM and UNHCR Available at: https://www.iom.int/news/refugeesand-migrants-venezuelatop-four-million-iom-andunhcr?utm_source=IOM+External+Mailing+List\&utm_campaign= e34c71ed9bEMAIL_CAMPAIGN_2019_06_06_07_16\&utm_medium=email\&utm_term=0_ 9968056566-e34c71ed9b-43648581. Accessed 15 Apr 2021.

Jennings, R. 1939. Some international law aspects of the refugee question. British Yearbook of International Law 20: 98-114.

Keller, S. 1975. Uprooting and social change: The role of refugees in development. Delhi: Manohar Book Service.

Lindo, P., Vende, J., Gonzales, E., Hing, K., Doughty, M., Gioannetti, A., Kenzie, R., Superville, S. and Loutoo, J., 2019. Govt issues 1,932 visas to Venezuelans - Trinidad and Tobago Newsday. [online] Trinidad and Tobago Newsday. Available at: https://newsday.co.tt/2019/10/09/visas-forvenezuelans-stopped-2/https://newsday.co.tt/2019/10/09/visas-for-venezuelans-stopped-2.

Malkki, L. 1995. Refugees and exile: From 'refugee studies' to the national order of things. Annual Review of Anthropology 24 (1): 493-523.

Mazur, R. 1989. The political economy of refugee creation in southern Africa: Micro and macro issues in sociological perspective. Journal of Refugee Studies 2 (4): 441-467.

Monitor, T. 2019. How a tiny island nation deals - or doesn't - with 40,000 Venezuelans. The Christian Science Monitor Available at: https://www.csmonitor.com/World/Americas/2019/0725/ How-a-tiny-island-nation-deals-ordoesn-t-with-40-000-Venezuelans. Accessed 23 Oct 2019.

Neaves, J. 2019. Young: No 'boatloads of Venezuelans'. Trinidad and Tobago Newsday Available at: https://newsday.co.tt/2019/06/26/young-no-boatloads-ofvenezuelans/?fbclid=IwAR2Ar2wc VYHM6951ZB-VAxLUWT4yZuSmxdTMWd4jX2licLtAmk3RfAu91Y. Accessed 23 Oct 2019.

Neaves, J., R. Kenzie, J. Vende, T. Gittens, S. Douglas, D. Bahaw, R. Kenzie, E. Gonzales, S. Douglas, and J. Loutoo. 2019. PM: We have done more for V'zuelans than any other country. Trinidad and Tobago Newsday Available at: https://newsday.co.tt/2019/07/23/pm-we-have-done-more-forvzuelans-than-any-other-country/.

Robbins, J. 2013. Beyond the suffering subject: Toward an anthropology of the good. Journal of the Royal Anthropological Institute 19 (3): 447-462.

Robertson, S. 2018. Status-making: Rethinking migrant categorization. Journal of Sociology 55 (2): 219-233. 
Rosas, E. 2019. Open letter to Keith Christopher Rowley Prime Minister of Trinidad and Tobago. Amnesty.org Available at: https://www.amnesty.org/download/Documents/AMR4905062019EN GLISH.pdf. Accessed 7 Nov 2019.

Scheel, S., and P. Ratfisch. 2013. Refugee protection meets migration management: UNHCR as a global police of populations. Journal of Ethnic and Migration Studies 40 (6): 924-941.

Stein, B. 1981. The refugee experience: Defining the parameters of a field of study. International Migration Review 15 (1/2): 320.

Surtees, J. 2019. Venezuelan refugees feared drowning en route to Trinidad. The Guardian Available at: https://www.theguardian.com/world/2019/apr/25/venezuelanrefugees-feared-drowned-trini dad-boat-sinks. Accessed 28 Oct 2019.

Teff, M., 2019. Forced into Illegality: Venezuelan Refugees and Migrants in Trinidad and Tobago Refugees International. [online] Refugees International. Available at: https://www.refugeesin ternational.org/reports/2019/1/27/forced-into-illegality-venezuelan-refugees-and-migrants-in-trini dad-and-tobago.

UNHCR. 2021. Venezuela situation. [online] Available at: https://www.unhcr.org/venezuela-emergency. html.

UNHCR, D., 2019. Situation Venezuela. [online] Data2.unhcr.org. Available at: https://data2.unhcr.org/ en/situations/vensit. Accessed 28 Oct 2019.

UN Geneva Convention, R. 1951. Convention and protocol relating to the status of refugees. UNHCR Available at: https://www.unhcr.org/3b66c2aa10. Accessed 30 Apr 2021.

Zetter, R. 1991. Labelling refugees: Forming and transforming a bureaucratic identity. Journal of Refugee Studies 4 (1): 39-62.

Zetter, R. 2007. More labels, fewer refugees: Remaking the refugee label in an era of globalization. Journal of Refugee Studies 20 (2): 172-192.

\section{Comments}

Publisher's Note Springer Nature remains neutral with regard to jurisdictional claims in published maps and institutional affiliations. 